\title{
LUDWIGIA PEPLOIDES (KUNTH.) P.H. RAVEN - FLOATING WATER PRIMROSE, A NEW SPECIES IN CROATIAN FLORA FROM THE LIST OF INVASIVE ALIEN SPECIES OF UNION CONCERN
}

\section{Suzana BuzjaK \& Zorana Sedlar}

Department of Botany, Croatian Natural History Museum, Demetrova 1, HR-10 000 Zagreb, Croatia

Buzjak, S. \& Sedlar, Z.: Ludwigia peploides (Kunth.) P.H. Raven - Floating Water Primrose, a new species in Croatian flora from the list of invasive allochthonous species of Union concern. Nat. Croat. Vol. 27, No. 2, 351-356, 2018, Zagreb.

The species Ludwigia peploides - the floating water primrose, one of the species listed as IAS of EU concern (Regulation EU No 1143/2014) has been recorded for the first time in Croatian flora. It was recorded at the end of August 2018 on the Ilova River near the village of Kaniška Iva (Moslavina, Croatia) where it forms dense floating mats. Its presence was observed along a length of the river of about $2 \mathrm{~km}$. With this finding there are now six plant species listed as invasive alien species of Union concern present in Croatia.

Key words: river, Ilova, macrophytes, allochthonous species, distribution

Buzjak, S. \& Sedlar, Z.: Ludwigia peploides (Kunth.) P.H. Raven - plutajuća mekčina, nova vrsta za floru Hrvatske s popisa invazivnih stranih svojti koje izazivaju zabrinutost u Uniji. Nat. Croat. Vol. 27, No. 2, 351-356, 2018, Zagreb.

Vrsta Ludwigia peploides - plutajuća mekčina, nalazi se na popisu invazivnih stranih vrsta koje izazivaju zabrinutost u Uniji i nova je vrsta za floru Hrvatske. Zabilježena je krajem kolovoza 2018. godine na rijeci Ilovi u blizini mjesta Kaniška Iva (Moslavina) gdje raste u nakupinama. Njezina prisutnost zabilježena je na riječnom toku u dužini od oko $2 \mathrm{~km}$. S ovim nalazom sada je u Hrvatskoj prisutno šest biljnih vrsta koje su na popisu invazivnih stranih vrsta koje izazivaju zabrinutost u Uniji.

Ključne riječi: rijeka, Ilova, makrofiti, alohtone vrste, rasprostranjenost

Ludwigia peploides (Kunth.) P.H. Raven (Onagraceae) is an emergent and floating herbaceous perennial aquatic plant (Fig. 1). The native distribution of L. peploides is in South and Central America, and Southern part of the USA. There is contradictory information about its distribution in Australia and New Zealand, stating it could be native or introduced (CABI, 2018; EPPO, 2011a; EPPO, 2011b; USDA-ARS, 1997). It was introduced to Montpellier (France) in the 1830s, presumably as ornamental and during the $20^{\text {th }}$ century became one of the most widespread and detrimental aquatic invasive plants in the country (DANDELOT et al., 2005). During the same period it has been recorded in many European countries: Belgium, France (including Corsica), Germany, Greece, Italy, the Netherlands, Portugal, Spain, Switzerland, Turkey and the UK (Fig. 2); and in the rest of the world: Africa and Asia; Turkey, Southeast Asia, Taiwan, Japan (CABI, 2018; EPPO 2011a; EPPO, 2011b). 

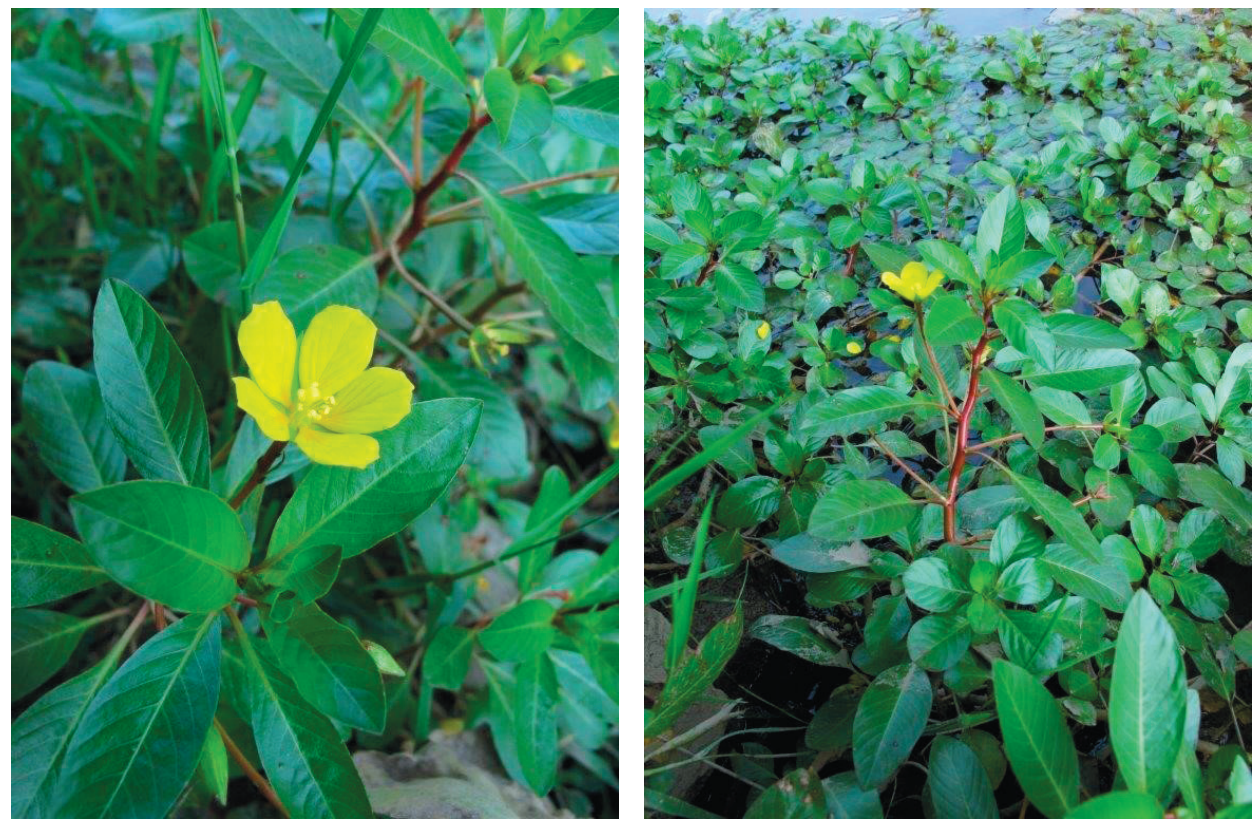

Fig. 1. Habitus of Ludwigia peploides.

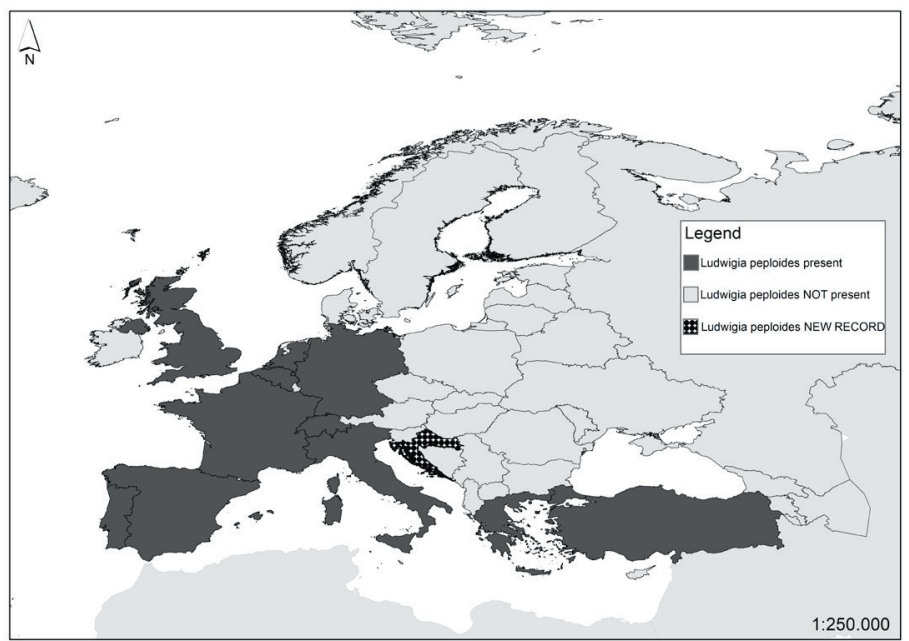

Fig. 2. Distribution of Ludwigia peploides in Europe, including the new finding in Croatia.

The floating water primrose has glabrous or pubescent stems of $10-300 \mathrm{~cm}$ that creep horizontally or grow vertically (but never strongly erect). In early spring rosette-like clusters of rounded floating leaves appear. Leaves are alternate, with highly variable shape, petiolate, less than $10 \mathrm{~cm}$ long and oblong to round $(1-6 \times 0.4-3 \mathrm{~cm})$. During flowering period, leaves on floating shoots are as described, while on vertical shoots are more lanceolate. It has roots, used for absorption of nutrients and attachment of the plant to the soil, and adventitious roots, from submerged nodes, ensuring oxygen uptake and favoring rooting of plant fragments (cuttings). Flowers developing individually in leaf 
axils are pentamerous, with bright yellow petals, 9 to 16 (22) $\mathrm{mm}$ long, and green sepals, 6-14 mm long. Bracteoles, placed at ovarium base, are deltate or ovate. The fruit is a cylindrical, five-angled capsule of 13-32 mm long and 3-4 mm wide with 40-50 seeds of 1.0-1.5 mm in length (EPPO, 2011b; Jepson Flora Project, 2018; Raven, 1986).

Similar species, Ludwigia grandiflora (Michx.) Greuter \& Burdet, a large-flowered water primrose and Ludwigia hexapetala (Hook. \& Arn.) Zardini, H.Y. Gu \& P.H. Raven a Uruguayan waterprimrose are very difficult to differentiate and they are often confused with L. peploides especially with L. peploides subsp. montevidensis (Spreng.) P.H. Raven. The L. grandiflora and $L$. hexapetala have stems that also creep horizontally on the surface of the water but the flower shoots are strongly erect and up to one meter high, bracteoles are lanceolate to lance-ovate and petals are generally larger, 15 - 29 mm long (EPPO, 2011b; Robert et al. 2013; Jepson Flora Project, 2018).

L. peploides is mainly aquatic but can also colonize damp terrestrial habitats such as riverbanks or wet meadows. In its native range, it occurs in wetlands (Rolon et al., 2008) and in the transition zone between aquatic and terrestrial environments (HERNANDEZ \& RANGEL, 2009). Elsewhere, establishment habitats of L. peploides often include wet margins of ponds and lakes, stagnant or slow-flowing waters, rivers, shallow ponds and lakes, canals, wetlands, ditch networks, sediment bars on river borders, in wet meadows and in brackish waters (EPPO, 2011a; Zото et al., 2006).

Survival strategies include perennial vegetative organs (cuttings of roots and stems) and prolific seed production. Fragmentation of stems and dispersion through water flow is the main mode of dispersal of Ludwigia spp. The sexual reproduction and seed dispersal could become an additional mechanism for winter survival and spread of Ludwigia, especially over long distances (RuAux et al., 2009).

During field work at the end of August (30 August 2018) Ludwigia peploides was found on the Ilova River (Fig. 3), near the village of Kaniška Iva, in the vicinity of town of Garešnica (HTRS96: X 534021; Y 5042382). The river is rather canalized (Fig. 4) and is surrounded by ponds. It is about 7 meters wide and $0.5-1 \mathrm{~m}$ deep with a bottom

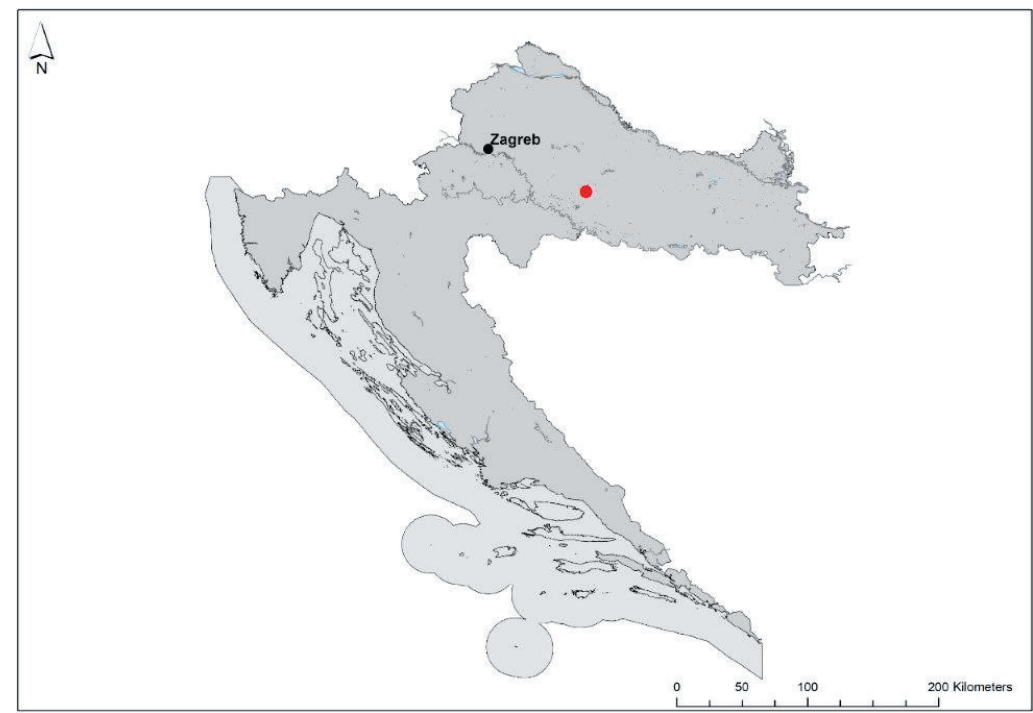

Fig. 3. The location of the Ilova River in which Ludwigia peploides was recorded. 
covered with mud. The banks are covered with regularly mown grasslands. The right bank is at about $45^{\circ}$, while the left is at an angle of $25^{\circ}$. The research of this particular area comprised $2 \mathrm{~km}$ of the course of the Ilova River, on which L. peploides was found at many scattered localities forming dense floating mats, about 1 square meter surface (Fig. 5). Some other plants found on the river together with L. peploides were Ceratophyllum demersum L., Typha latifolia L., Polygonum mite Schrank, Sparganium erectum L., Bidens frondosa L., Najas marina L., Leersia oryzoides (L.) Sw. The Ilova River was also checked for the presence of L. peploides upstream and downstream for distances of approximately $5 \mathrm{~km}$ and L. peploides was not found. Specimens of L. peploides were collected and vouchers are stored in the Herbarium collection of the Croatian Natural History Museum (CNHM) under inventory number 600:ZAG; 8305:BOB.
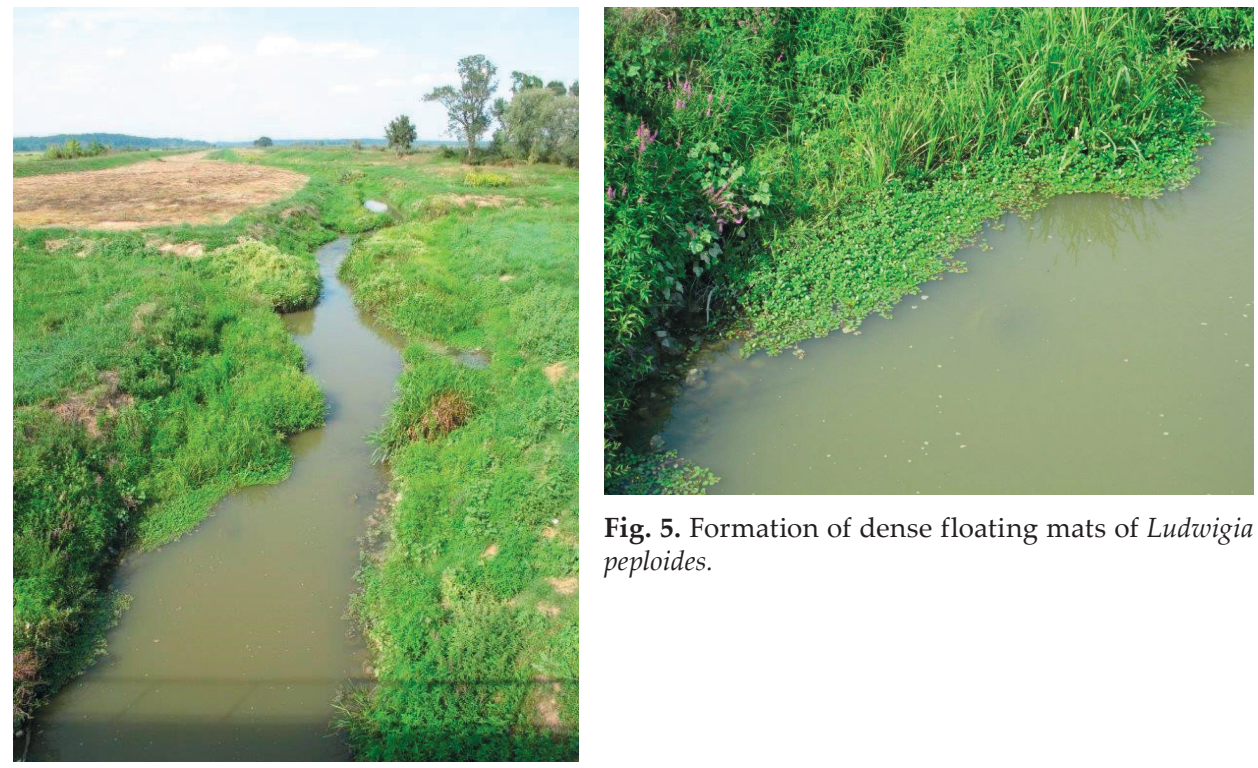

Fig. 5. Formation of dense floating mats of Ludwigia peploides.

Fig. 4. Ludwigia peploides habitat in Croatia on the Ilova river.

L. peploides is considered to have been introduced into Europe as an ornamental aquatic plant. There are no known pathways of its introduction into Croatian territory. However, a possible pathway may include the availability of internet purchase of creeping water primrose for aquarium or a garden pond purposes from which it could have spread into natural habitats. According to Regulation EU 1143/2014 on the prevention and management of the introduction and spread of invasive alien species (EU, 2014), creeping water primrose is on the list of invasive alien species of Union concern (EC, 2016; EC, 2017). The Republic of Croatia has, as a member of the European Union, an obligation to implement rapid eradication of this species and prevent further spread. Its distribution is still limited in the European countries in which it is recorded or its invasions are at an early stage, except in France (CABI, 2018; EPPO, 2011b, RoBert at al. 2013) and we can hope that this same limitation will be effectuated in Croatia. Mechanical control is possible but should be carried out with precaution so not to produce more fragments which may disperse the plants further. Herbicides are available for chemical management but their use in the natural environment is not recommended (EPPO, 2011b). 
Including data presented in this paper there are now six plant species present in Croatia on the list of invasive alien species of Union concern (EC, 2016; EC, 2017; INvasive alien species in Croatia, 2018; Nikolić, 2018).

Received November 23, 2018

\section{REFERENCES}

CABI, 2018: Ludwigia peploides (water primrose) [original text by Alison Mikulyuk]. In Invasive Species Compendium. Wallingford, UK: CAB International. www.cabi.org/isc. Date of access 15/11/2018.

EC, 2016: Commission Implementing Regulation (EU) 2016/1141 of 13 July 2016 adopting a list of invasive alien species of Union concern pursuant to Regulation (EU) No 1143/2014 of the European Parliament and of the Council. Official Journal of the European Union L 189, 14.7.2016, 4-8. Available at: http:// eur-lex.europa.eu/legal-content/EN/TXT/?qid=1468477158043\&uri=CELEX:32016R1141

EC, 2017: Commission Implementing Regulation (EU) 2017/1263 of 12 July 2017 updating the list of invasive alien species of Union concern established by Implementing Regulation (EU) 2016/1141 pursuant to Regulation (EU) No 1143/2014 of the European Parliament and of the Council. Official Journal of the European Union L 182, 13.7.2017, 37-39. Available at: http://eur-lex.europa.eu/legal-content/ EN/TXT/?uri=CELEX:32017R1263

Dandelot, S., Verlaque, R., Dutartre, A., Cazaubon, A., 2005: Ecological, dynamic and taxonomic problems due to Ludwigia (Onagraceae) in France. Hydrobiologia 551 (1), 131-136.

EPPO, 2011a: European and Mediterranean Plant Protection Organization. Pest Risk Analysis for: Ludwigia peploides. Available at https://gd.eppo.int/taxon/LUDPE/documents

EPPO, 2011b: EPPO data sheet on Invasive Alien Plants: Ludwigia grandiflora and L. peploides Onagraceae - Water primroses. Bulletin 41(3), 414-418. Available at: https://doi.org/10.1111/j.1365-2338.2011.02511.x

EU, 2014: Regulation (EU) 1143/2014 of the European Parliament and of the Council of 22 October 2014 on the prevention and management of the introduction and spread of invasive alien species. Official Journal of the European Union L 317, 4.11.2014, 35-55. Available at: http://eur-lex.europa.eu/legalcontent/EN/TXT/?qid=1417443504720\&uri=CELEX:32014R1143

Hernandez, R. \& Rangel, C., 2009: Vegetation of the wetland Jaboque (Bogotá, D.C.). Caldasia 31, 355379.

Invasive Alien SPecies in Croatia (Invazivne vrste u Hrvatskoj), 2018; http://www.invazivnevrste.hr/ [accessed on Nov 15, 2018].

Jepson Flora Project (eds.), 2018: Jepson eFlora, http://ucjeps.berkeley.edu/eflora/ [accessed on Nov 15, 2018].

Raven, P. H., 1968: Ludwigia peploides (Kunth) P.H. Raven. In Tutin T.G., Heywood V.H., Burges N.A., Moore D.M., Valentine D.H., Walters S.M., Webb D.A., eds. Flora Europaea 2. Cambridge: Cambridge University Press, 308 pp.

Nikolić, T. (ed.), 2018: Flora Croatica Database. On-Line (http://hirc.botanic.hr/fcd). Department of Botany and Botanical Garden, Faculty of Science, University of Zagreb, Zagreb. [accessed on Nov 14, 2018].

Robert, H., Lafontaine, R.-M., Beudels-Jamar, R.C. \& Delsinne, T., 2013: Risk analysis of the Water Primrose Ludwigia peploides (Kunth) P.H. Raven. - Risk analysis report of non-native organisms in Belgium from the Royal Belgian Institute of Natural Sciences for the Federal Public Service Health, Food chain safety and Environment. $35 \mathrm{pp}$.

Rolon, A.S., Lacerda, T., Maltchik, L. \& Guadagnin, D.L., 2008: Influence of area, habitat and water chemistry on richness and composition of macrophyte assemblages in southern Brazilian wetlands. Journal of Vegetation Science 19, 221-228.

Ruaux, B., Greulich, S., Haury, J. \& Berton, J.P., 2009: Sexual reproduction of two alien invasive Ludwigia (Onagraceae) on the middle Loire River, France. Aquatic Botany 90(2), 143-148.

USDA-ARS, 1997: Germplasm Resources Information Network (GRIN): Ludwigia peploides (Kunth) P. H. Raven. Online Database. Beltsville, Maryland, USA: National Germplasm Resources Laboratory. Available at: https://npgsweb.ars-grin.gov/gringlobal/taxonomydetail.aspx?id=400071

Zotos, A., Sarika, M., Lucas, E. \& Dimopoulos, P., 2006: Ludwigia peploides subsp. montevidensis, a new alien taxon for the flora of Greece and the Balkans. Journal of Biological Research 5, 71-78. 


\section{SAŽETAK \\ Ludwigia peploides (Kunth.) P.H. Raven - plutajuća mekčina, nova vrsta za floru Hrvatske s popisa invazivnih stranih svojti koje izazivaju zabrinutost u Uniji}

\section{S. Buzjak \& Z. Sedlar}

Vrsta Ludwigia peploides - plutajuća mekčina, višegodišnji je makrofit koji je prirodno rasprostranjen na području Južne i Centralne Amerike te u južnom dijelu SAD-a, a po nekima i u Australiji i Novom Zelandu. U Europu je unesena 1830-tih u Montpellier (Francuska) i to vjerojatno kao ukrasna biljka te se proširila i postala vrlo invazivna. Od tada je u Europi pronađena u Belgiji, na Korzici, Grčkoj, Italiji, Nizozemskoj, Španjolskoj, Švicarskoj, Turskoj i u Velikoj Britaniji gdje je ograničene rasprostranjenosti ili je njena invazivnost tek $u$ početnom stadiju. Vrsta se nalazi na popisu invazivnih stranih vrsta koje izazivaju zabrinutost u Uniji te je nova vrsta za floru Hrvatske. Zabilježena je krajem kolovoza 2018. godine na rijeci Ilovi u blizini mjesta Kaniška Iva (Moslavina) gdje raste u nakupinama na dužini toka od oko $2 \mathrm{~km}$. Način na koji je došla u Hrvatsku nije poznat. Međutim, mogući put ulaska na teritorij Hrvatske uključuje dostupnost ove vrste za nabavu te korištenje u akvaristici odakle je možda dospjela u prirodu. Hrvatska kao članica Europske Unije dužna je nakon ranog otkrivanja invazivnih stranih vrsta s Unijinog popisa primijeniti mjere iskorjenjivanja u ranoj fazi invazije, vodeći računa o zdravlju ljudi i okolišu. S ovim nalazom sada je u Hrvatskoj prisutno šest biljnih vrsta koje su na popisu invazivnih stranih vrsta koje izazivaju zabrinutost u Uniji. 